\title{
Kitz-Wilson Mechanisms of Action of Neostigmine and Penicillin
}

\author{
T.A. Alston \\ Department of Anesthesia and Critical Care, Massachusetts General Hospital, Harvard Medical School, Boston, MA \\ 02114, USA
}

\begin{abstract}
The molecular mechanism of penicillin action is closely analogous to that of neostigmine. Both drugs react covalently with the active-site serine of their target enzymes. In both cases, the susceptible enzymes self-catalyze their inactivation by their respective drugs. Kinetic analysis of cholinesterase by Richard J. Kitz and Irwin B. Wilson helped to establish that concept. Neostigmine and penicillin are kindred examples of mechanism-based enzyme inhibition, a generally important phenomenon in pharmacology and physiology.
\end{abstract}

\section{INTRODUCTION}

Anesthesiologists often deploy anti-enzymes. For instance, we use carbamates as anticholinesterases and $\beta$ lactams as antibiotics. How do they work?

As anti-enzymes, the mechanisms of the Physostigma carbamate and the Penicillium B-lactam are much the same. Both prototype drugs evolved in nature as, literally, chemical weapons meant to attack serine enzymes. Serine is one of the amino acids comprising the active pockets of the thus-named enzyme proteins, and serine directly participates in the catalytic functions of those enzymes. Carbamates and $\beta$-lactams covalently attach to that particular serine and thereby block the active sites of their target enzymes. Richard J. Kitz and Irwin B. Wilson showed why the inactivators can be highly effective. That is, susceptible serine enzymes actively catalyze their own inactivation by the anti-enzyme molecules [1].

\section{CHOLINESTERASE}

Serine enzymes have a two-step catalytic mechanism [2]. For instance, cholinesterase catalyzes the transfer of an acetyl group from acetylcholine to water in two steps (Fig. 1).

In step one, the serine of cholinesterase accepts the acetyl group from acetylcholine, and choline leaves the active site of the enzyme. In step two, the acetylated enzyme passes the acetyl group to an incoming water molecule [2].

\section{Carbamate Inactivators}

Neostigmine is a "false substrate" for cholinesterase [3]. The inhibitor resembles acetylcholine and docks into the active site of the enzyme much as acetylcholine does (Fig. 2). Neostigmine is then well poised to transfer its carbamyl group to the enzymatic serine in step one.

Step one is facilitated by the ease with which the cholinelike part of neostigmine can function as a "leaving group."

One way to compare the leaving group of acetylcholine with that of neostigmine is to consider how tightly the two

*Address correspondence to this author at the Department of Anesthesia and Critical Care, Massachusetts General Hospital, Harvard Medical School, Boston, MA 02114, USA; E-mail: talston@partners.org leaving alcohols hold onto hydrogen ions. The $\mathrm{pK}_{\mathrm{a}}$ value of an acid is the $\mathrm{pH}$ value at which the acid is $50 \%$ ionized at equilibrium. A low $\mathrm{pK}_{\mathrm{a}}$ value indicates strong acidity. Neostigmine alcohol $\left(\mathrm{pK}_{\mathrm{a}}=9\right)$ is 100,000 times more acidic than choline $\left(\mathrm{pK}_{\mathrm{a}}=14\right)$. This marked leaving ability allows an otherwise poorly transferable carbamyl group to be released to cholinesterase.

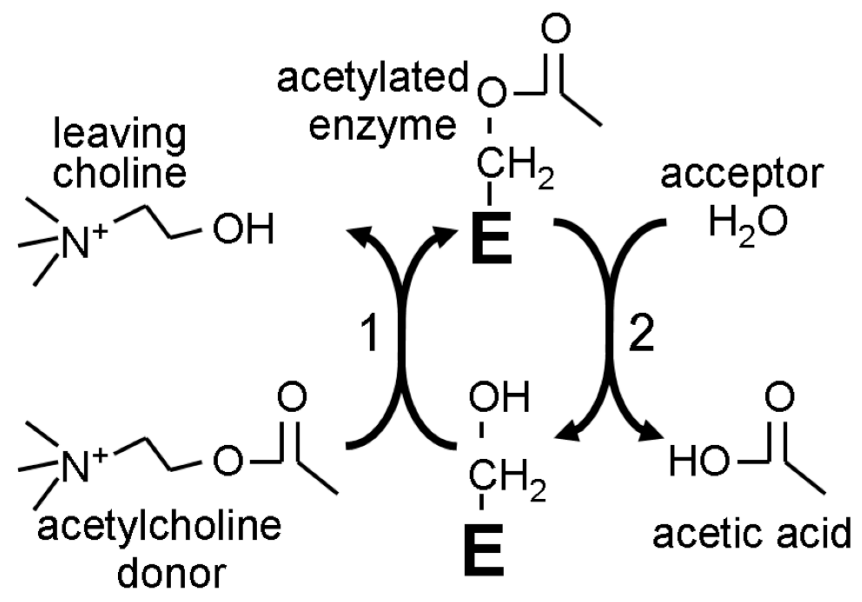

Fig. (1). The two-step mechanism of cholinesterase. $\mathrm{HO}-\mathrm{CH}_{2}-$ is part of serine, an amino acid in the active site of the enzyme (E). In step 1, the serine of cholinesterase takes the acetyl group from the departing choline. In step 2, the acetyl-enzyme passes the acetyl group to a receiving water molecule.

Cholinesterase thus takes the carbamyl group from neostigmine, but the carbamylated enzyme passes the poorly transferable carbamyl group to water at only a small fraction of the acetyl transfer rate. Instead of microseconds for an acetyl group, cholinesterase takes minutes to transfer a tenacious carbamyl attachment to water [3]. The enzyme is thus covalently inhibited through exploitation of its vulnerable two-step mechanism.

\section{Organophosphorus Inactivators}

The organophosphate anticholinesterases are comprised of even poorer transferable groups (phosphoryl groups) attached to even better leaving groups. Echothiophate is an organophosphate that particularly resembles acetylcholine 
and is shown in Fig. (2). It docks onto the enzyme and passes its poised phosphoryl group to the serine much like an acetyl group is ordinarily passed. However, the phosphoryl group forms an extraordinarily strong bond to the cholinesterase serine. High stability of the phosphoryl linkage to the serine (and the availability of radioactive ${ }^{32} \mathrm{P}$ ) helped to establish serine as the acetyl-carrying part of the cholinesterase protein [4-6].

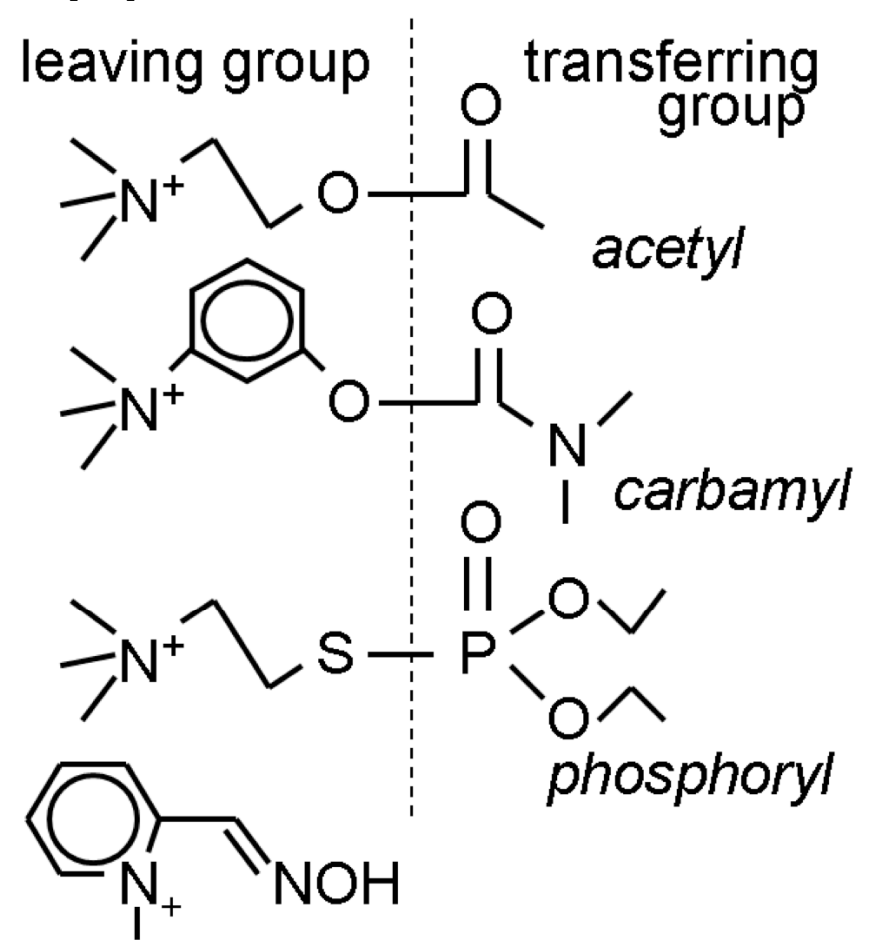

Fig. (2). Structural diagrams of acetylcholine and representative carbamate and phosphate analogs. Shown are neostigmine, familiar as a reversal agent for neuromuscular blockade, and echothiophate, used to treat glaucoma. All three molecules donate a transferring group to cholinesterase. However, unlike the acetyl-enzyme, the carbamyl- or phosphoryl-enzymes are resistant to reactivation by water. The respective half-lives of the covalently modified enzyme are approximately $1 \mu \mathrm{sec}, 20 \mathrm{~min}$, and $>1$ day. $^{3}$ Shown at the bottom is pralidoxime, which serves as a reactive analog of choline and can, on that basis, remove the phosphoryl group from the echothiophate-poisoned enzyme

Small serine-containing peptides do not react with neostigmine or echothiophate. The serine of cholinesterase reacts with those drugs because the complete enzyme holds the acetylcholine-resembling drugs up to the serine. They are held in proximity to the serine and in proper alignment for reaction with that amino acid. In so doing, the enzyme catalyzes its own inactivation by the [1].

\section{Kitz-Wilson Kinetics}

Early support for the concept that an enzyme can catalyze its inactivation was provided by kinetic analyses of Kitz and Wilson (Fig. 3) [1].

If cholinesterase did not enzymatically facilitate the covalent modification of its serine by anticholinesterases, then the rate of enzyme inactivation would increase linearly with increasing inactivator concentration. Instead, the rate of inac- tivation reaches a maximal value at low inactivator concentrations (Fig. 4). Therefore, a noncovalent enzyme-inactivator complex is formed before covalent reaction occurs. The noncovalent enzyme-inactivator complex is analogous to the enzyme-substrate complex of Michaelis and Menten [1, 3, 7].

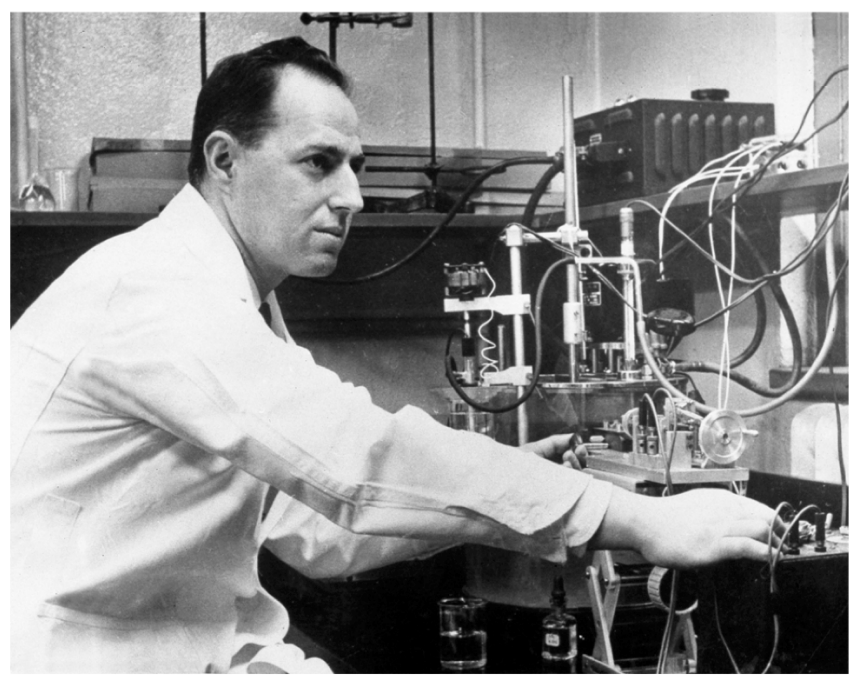

Fig. (3). Irwin B. Wilson, the scientist largely responsible for the understanding of the anticholinesterase mechanism. For many years that concept was the most "molecular" drug mechanism in the esteemed Goodman and Gilman pharmacology textbook. Photographed by Richard J. Kitz at Columbia-Presbyterian Medical Center in 1962, he is at the controls of a $\mathrm{pH}$-stat device used to titrate the velocity at which cholinesterase liberates acetic acid from acetylcholine.

The paired name Michaelis-Menten is an eponym for the kinetic pattern of most enzyme substrates, and Kitz-Wilson is an eponymous term for the kinetic pattern of many enzyme inactivators.

\section{Oxime Reactivator of Cholinesterase}

With Sara Ginsburg, Wilson found another way to emphasize that cholinesterase catalyzes its inactivation by anticholinesterases; they invented a means for the organophosphate-poisoned enzyme to catalyze its re-activation. Although cholinesterase cannot effectively transfer attached phosphoryl groups to water, the poisoned enzyme can transfer those poorly transferable groups to choline. Since the choline molecule is larger than the water molecule, the enzyme active site is better able to position choline than it can position water molecules for reaction with enzyme-bound phosphate. Similarly, by means of the choline-like drug pralidoxime (Fig. 2), cholinesterase self-catalytically rescues itself from organophosphate poisons [8-10]. Pralidoxime is more reactive than choline and was arguably the first drug to be designed de novo on chemical principles.

\section{BACTERIAL TRANSPEPTIDASE}

The bacterial cell wall is cross-linked in much the same way that mammalian acetylcholine action is terminated; a serine enzyme covalently carries a transferable group from a donor molecule to an acceptor in two steps (Fig. 5). The enzyme that cross-links together the bacterial cell-wall peptidoglycan is called a transpeptidase. Before cross-linking, the 
blocks of peptidoglycan bear peptide strands that end with the amino acid D-alanine. In a first step, the transpeptidase splits off the terminal D-alanine (as if that were choline). In step two, the serine-linked material is transferred to the incoming amino group of another molecule of peptidoglycan (Fig. 5).

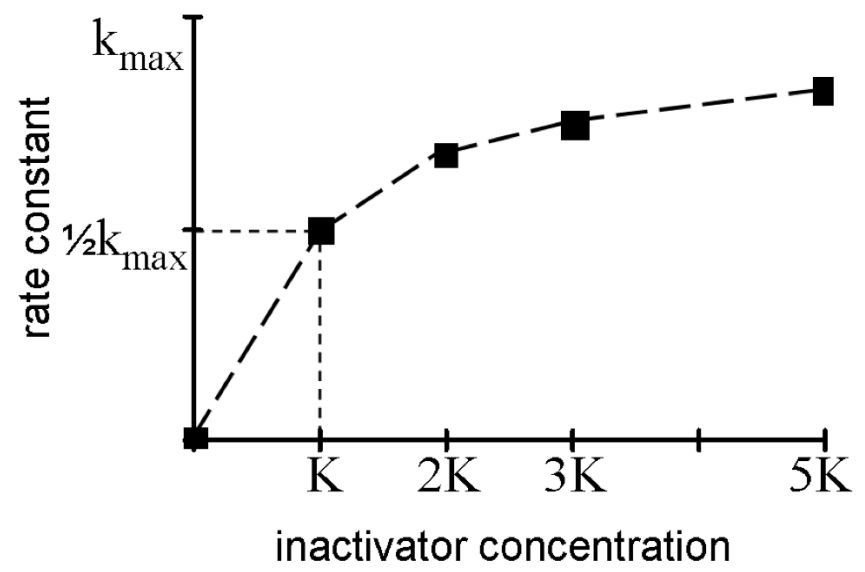

Fig. (4). Kitz-Wilson kinetics. The apparent rate constant for inactivation of cholinesterase does not increase linearly with increasing inactivator concentration [1]. The inactivator forms a noncovalent complex characterized by dissociation constant K. The enzyme converts the noncovalent complex to the covalent compound in a self-catalyzed process with maximal rate constant $k_{\max }$. Therefore, the rate-concentration profile has the shape of a hyperbola. KitzWilson kinetic patterns for an enzyme inactivator are analogous to Michaelis-Menten patterns for a substrate $[1,3,7]$. The analogy indicates that cholinesterase catalyzes its undoing by anticholinesterases. The rate constants for inactivation are calculated from the half-lives of the enzyme in the presence of various inactivator concentrations $\left(\mathrm{k}=.69 / \mathrm{t}_{1 / 2}\right.$ where .69 is approximately the natural logarithm of 2) [1]. The calculations are relatively complicated when, as is the case of neostigmine, the enzyme has a recovery rate. Therefore, Kitz and Wilson first applied their kinetic analysis to the methane sulfonate analog of neostigmine [1]. That irreversible inhibitor happened to exhibit a $\mathrm{K}$ value of $0.4 \mathrm{mM}$ and a $\mathrm{k}_{\max }$ value of $.03 \mathrm{~min}^{-1}$ against the electric eel enzyme at $\mathrm{pH} 7$ and $25^{\circ} \mathrm{C}$. Therefore, the enzyme activity was lost with a half-time of $23 \mathrm{~min}$ in the presence of saturating inactivator $(23=.693 / .03)$ and a half-time of 46 min with $0.4 \mathrm{mM}$ inactivator.

\section{B-Lactams}

As neostigmine resembles acetylcholine, penicillin resembles a bit of cell-wall material [11-13]. The D-alaninelike part is ready to spring apart because it is held in a highly strained four-membered ring (Fig. 6). The ring strain facilitates step one for reaction of the serine of transpeptidase with penicillin. However, because of the ring, the terminal Dalanine-like part cannot fly away (as a leaving group) to make room for an incoming acceptor. The enzyme is thus trapped by a tethered "leaving" group (Fig. 6).

\section{CONCLUSIONS}

Neostigmine and penicillin are exogenous molecules, but the human body contains many endogenous proteins functioning as anti-enzymes for serine enzymes. Examples include antithrombin, antiplasmin, and antitrypsin. These proteinaceous anti-enzymes work much like the relatively small neostigmine and penicillin molecules. Like their small counterparts, the proteinaceous anti-enzymes resemble the normal substrates for the corresponding proteolytic enzymes. However, when the enzymatic serine attaches to the coiled antienzyme protein, the uncoiling of the anti-enzyme distorts the enzyme and so prevents detachment from the serine. Antithrombin and its congeners are thereby aptly called "molecular mousetraps" for their targeted serine enzymes $[14,15]$.

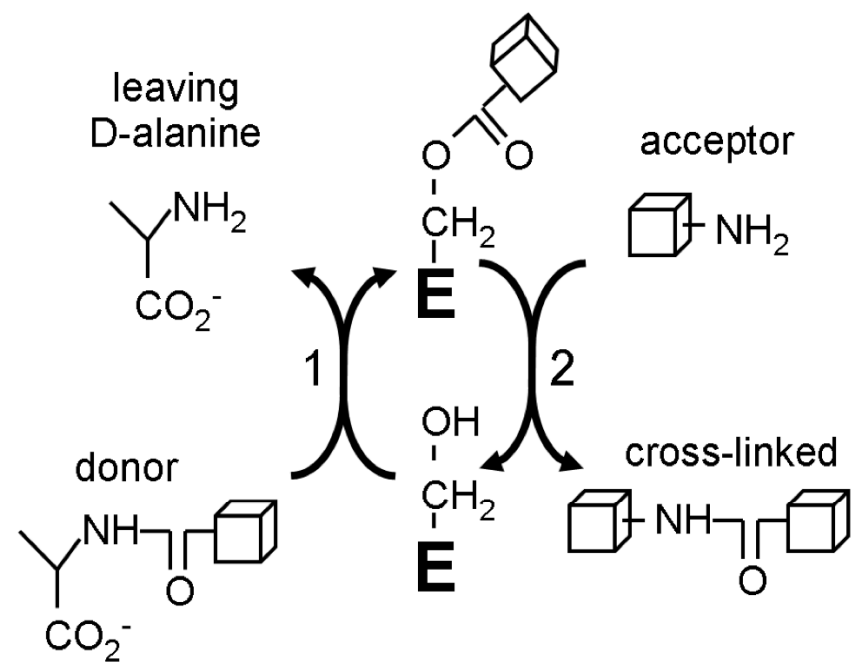

Fig. (5). The two-step transpeptidase reaction. A peptide bond in a block of peptidoglycan (represented by a cube) is enzymatically transferred from D-alanine $\left(\mathrm{NH}_{2}-\mathrm{CHCH}_{3}-\mathrm{CO}_{2}{ }^{-}\right)$to an amino group on a second molecule of peptidoglycan.

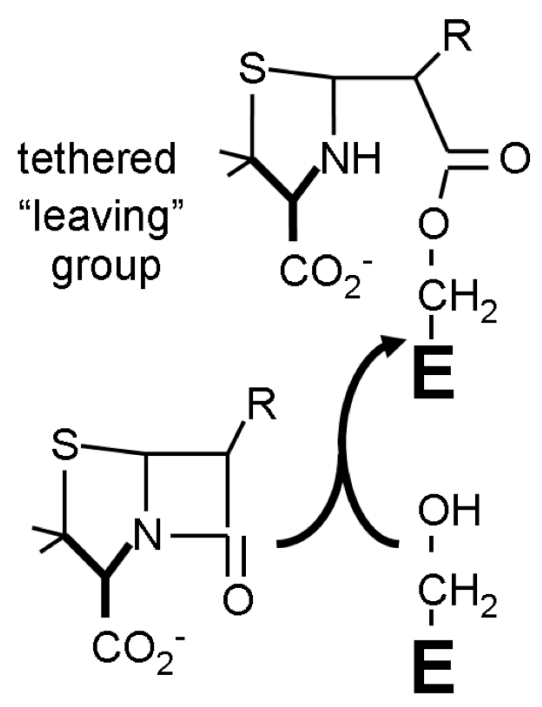

Fig. (6). Inactivation of bacterial transpeptidase by penicillin. The enzyme can only carry out step one of the two-step mechanism that is outlined in Figure 5. Step one (transfer to the serine of the enzyme) is irreversible because of the difficulty of reforming a strained four-membered ring. Step two (transfer from serine to an acceptor) is blocked since the D-alanine-like part of the antibiotic remains tied to the enzyme and denies acceptor molecules access to the active site. The lower left portion of the antibiotic is the part resembling D-alanine, the amino acid that ordinarily leaves in the transpeptidase reaction. The $\mathrm{R}$ group varies for each type of penicillin and is $\mathrm{C}_{6} \mathrm{H}_{5}-\mathrm{CH}_{2}-\mathrm{CO}-\mathrm{NH}$ - in the case of penicillin $\mathrm{G}$. 
Clinically useful mechanism-based inactivators of serine enzymes continue to be found in nature $[16,17]$ or designed by chemists [18]. The strategy began in 1877 when glaucoma was treated with the first 'stigmine [19].

\section{REFERENCES}

[1] Kitz RJ, Wilson IB. Esters of methanesulfonic acid as irreversible inhibitors of acetylcholinesterase. J Biol Chem 1962; 237(10): $3245-9$.

[2] Alexander J, Wilson IB, Kitz RJ. The reactivation of acetylcholinesterase after inhibition of methane-sulfonic acid esters. J Biol Chem 1963; 238(2): 741-4.

[3] Kitz RJ. Human tissue cholinesterase: rates of recovery after inhibition by neostigmine; Michaelis-Menten constants. Biochem Pharmacol 1964; 13(13): 1275-62.

[4] Boursnell JC, Webb EC. Reactions of esterases with radioactive diisopropyl fluorophosphonate. Nature 1949; 164(4177): 875.

[5] Abeles RH, Alston TA. Enzyme inhibition by fluoro compounds. J Biol Chem 1990; 265(28): 16705-8.

[6] de Jong RH. Nerve gas terrorism: a grim challenge to anesthesiologists. Anesth Analg 2003; 96(3): 819-25.

[7] Lee HJ, Wilson IB. Enzymic parameters: measurement of V and Km. Biochim Biophys Acta 1971; 242(3): 519-22.

[8] Wilson IB, Ginsburg S. A powerful reactivator of alkyl phosphateinhibited acetylcholinesterase. Biochim Biophys Acta 1955; 18(1): 168-70.

[9] Kitz RJ, Ginsburg S, Wilson IB. Activity structure relationships in the reactivation of diethylphosphoryl acetylcholinesterase by phenyl-1-methyl pyridinium ketoximes. Biochem Pharmacol 1965; 14(10): 1471-7.

[10] Alston TA. Edrophonium and pralidoxime. Anesth Analg 1989; 68(6): 826-7.

[11] Wise EM Jr, Park JT. Penicillin: its basic site of action as an inhibitor of a peptide cross-linking reaction in cell wall mucopeptide synthesis. Proc Natl Acad Sci USA 1965; 54(1): 75-81.

[12] Tipper DJ, Strominger JL. Mechanism of action of penicillins: a proposal based on their structural similarity to acyl-D-alanyl-Dalanine. Proc Natl Acad Sci USA 1965; 54(4): 1133-41.

[13] Yocum RR, Waxman DJ, Rasmussen JR, Strominger JL. Mechanism of penicillin action: penicillin and substrate bind covalently to the same active site serine in two bacterial D-alanine carboxypeptidases. Proc Natl Acad Sci USA 1979; 76(6): 2730-4.

[14] Huntington JA, Read RJ, Carrell RW. Structure of a serpinprotease complex shows inhibition by deformation. Nature 2000; 407(6806): 923-6.

[15] Huntington JA, Carrell RW. The serpins: nature's molecular mousetraps. Sci Prog 2001; 84(Pt 2): 125-36.

[16] Wierzbicki AS, Reynolds TM, Crook MA. Usefulness of Orlistat in the treatment of severe hypertriglyceridemia. Am J Cardiol 2002; 89(2): 229-31.

[17] Charnas RL, Knowles JR. Inactivation of RTEM beta-lactamase from Escherichia coli by clavulanic acid and 9-deoxyclavulanic acid. Biochemistry 1981; 20(11): 3214-9.

[18] Kotani K, Ichiba S, Andou M, et al. Extracorporeal membrane oxygenation with nafamostat mesilate as an anticoagulant for massive pulmonary hemorrhage after living-donor lobar lung transplantation. J Thorac Cardiovasc Surg 2002; 124(3): 626-7.

[19] Laqueur L. History of my glaucomatous illness. Am J Ophthalmol 1929; 12: 984-9.

(c) T.A. Alston; Licensee Bentham Open.

This is an open access article distributed under the terms of the Creative Commons Attribution License (http: //creativecommons.org/licenses/by/2.5/), which permits unrestrictive use, distribution, and reproduction in any medium, provided the original work is properly cited. 